\title{
DDIT3 wt Allele
}

National Cancer Institute

\section{Source}

National Cancer Institute. DDIT3 wt Allele. NCI Thesaurus. Code C92540.

Human DDIT 3 wild-type allele is located within 12q13.1-q13.2 and is approximately $4 \mathrm{~kb}$ in length. This allele, which encodes DNA damage-inducible transcript 3 protein, is involved in transcriptional suppression. Two translocations involving the gene, $\mathrm{t}(12 ; 16)$ $(q 13 ; p 11)$ with the FUS gene and $t(12 ; 22)(q 13 ; q 12)$ with the EWSR1 gene, are associated with myxoid liposarcoma. 